\title{
Phytochemical Profile and Antioxidant Activities of Aqueous Extract of Moringa oleifera (Lam) Collected from DR Congo and Kenya
}

\author{
Valence Bwana Mutwedu ${ }^{1,2, a, *}$, Albert Wafula Nyongesa ${ }^{3, b}$, Jafred Mulama Kitaa ${ }^{3, c}$, \\ Jemima Achieng Oduma ${ }^{4, d}$, James Mucunu Mbaria ${ }^{2, e}$ \\ ${ }^{I}$ Department of Animal Production, Faculty of Agriculture and Environmental Studies, Université Evangélique en Afrique (UEA), Bukavu, \\ Democratic Republic of the Congo \\ ${ }^{2}$ Department of Public Health, Pharmacology and Toxicology, Faculty of Veterinary Medicine, University of Nairobi, P. O. Box 29053- \\ 00625, Nairobi, Kenya \\ ${ }^{3}$ Department of Veterinary Anatomy and Physiology, Faculty of Veterinary Medicine, University of Nairobi, P.O Box 30197-00100, \\ Nairobi, Kenya \\ ${ }^{4}$ Department of Clinical Studies, Faculty of Veterinary Medicine, University of Nairobi, P.O. Box 29053-00625, Nairobi, Kenya
}

*Corresponding author

A R T I C L E I N F O A B S T R A C T

Research Article

Moringa oleifera Lam. is one of the most used plants in traditional medicine because of its high antioxidant properties. The antioxidant value, nonetheless, depends on locality where the plant is grown as well as specific parts on the plant. In this study, a phytochemical and antioxidant activity comparison of $M$. oleifera leaves, seeds and barks were carried out. Fresh leaves, seeds and barks were

Received : 19/11/2021

Accepted : 25/11/2021 collected from 2 to 3 years old M. oleifera trees of Bukavu city of South Kivu province in DRC and Masii village of Machackos County in Kenya. A total of $300 \mathrm{~g}$ of each dried sample powder was mixed with $700 \mathrm{~mL}$ of distilled water. Qualitative and quantitative assessment of alkaloids, saponins, phenols, flavonoids, glycosides, terpenoids and tannins were performed following standard methods while the antioxidant activity was assessed using the 2,2-diphenyl-1-picrylhydrazyl (DPPH) assay. Results indicate that only alkaloids were absent in leaves from Kenya and DRC while phenols, flavonoids and

Keywords: tannins were absent in barks. Glycoside in seeds from DRC had the highest concentration $(6.17 \%)$

Moringa oleifera

Antioxidant capacity

Oxidative stress

followed by alkaloids in seeds from Kenya (5.56\%). There was low concentration of terpenoids and flavonoids in all samples compared to other compounds. The highest extract yield was found in leaves Bukavu city

Machakos county from DR Congo (22.5\%) and seeds from Kenya (20\%). At the highest concentration $(10 \mu \mathrm{g} / \mathrm{mL})$, leaves from Kenya $(88.29 \pm 1.12 \mu \mathrm{g} / \mathrm{mL})$ and DRC $(80.17 \pm 3.59 \mu \mathrm{g} / \mathrm{mL})$ had the highest percentage inhibition of reactive oxygen-free radicals but lower than the reference standard $(92.63 \pm 2.76 \mu \mathrm{g} / \mathrm{mL})$. Leaves from Kenya $(23.59 \mu \mathrm{g} / \mathrm{mL})$ and DRC $(28.67 \mu \mathrm{g} / \mathrm{mL})$ had the highest IC50 compared to mean values of seeds and barks from the two countries. M. oleifera leaves, especially from Kenya, are recommended as a satisfactory antioxidant but can be substituted with seeds and/or barks in order to alleviate the use of leaves which are overused these days. \footnotetext{
a-1mutweduvalence@gmail.com ejamesmbariam@gmail.com

\section{Introduction}

Oxidative stress is defined as a physiological disturbance when the production of potentially destructive reactive oxygen species (ROS) exceeds the body's own natural antioxidant defense (Tremellen, 2008; Nimse and Pal, 2015; Mohammed et al., 2020). It has been associated with several chronic diseases such as diabetes, hypertension, inflammation, cancer, reproductive impairment in both humans and livestock (Nimse and Pal, 2015; Sevindik et al., 2018; Mutwedu et al., 2021) through DNA damage, lipid peroxidation, tissue injury and protein degradation (Unuigbe et al., 2014; Pehlivan et al., 2018). Research findings have shown that humans affected with such ailments often revert to use of synthetic antioxidants, which have been proven to quench or trap ROS (Nimse and Pal, 2015; Sevindik, 2019). However, due to healthy lifestyles and poverty especially in rural areas, the use of these synthetic antioxidants has increasingly declined in favor of dietary sources of antioxidants (Ibrahim et al., 2013; Bal et al., 2020).

In recent years, extensive research on medicines derived from plants have been focused on treatment of a wide variety of clinical diseases. On the one hand, plants are widely preferred due to their availability and low toxicity, while on the other hand, they are considered as pure and ecologically 
friendly for treatment of various ailments (Molla et al., 2012; Vijayakumar et al., 2012; Ikpeme et al., 2012). Several studies reported the beneficial effects of medicinal plants on many diseases including gastrointestinal and respiratory disorders (Ojewole and Amabeoku, 2006), hepatotoxicity (Ekor et al., 2006), fertility impairment and improvement (Ngoumtsop et al., 2017).

$M$. oleifera, a tree growing up to 5 to $12 \mathrm{~m}$ high with an open umbrella-shaped crown, is the most widely cultivated species of the Moringaceae family (Mahmood et al., 2010). It is widely distributed all over the world including India, Himalayan tracts, Pakistan, and Africa and can be found even in the hardest and driest soils (Luqman et al., 2012). Due to its several traditional medicinal properties, industrial and nutritional uses, this plant is considered as one of the most beneficial trees in the world (Anwar et al., 2007; Wadhwa, 2013. In fact, all parts of M. oleifera including leaves, gum, root, bark, flowers, fruit (pods), seed and seed oil are highly nutritious and contain important minerals, proteins, vitamins, antioxidants, $\beta$ carotene, amino acids and various phenolic compounds (Anwar et al., 2007).

The leaves of $M$. oleifera are edible by both humans and animals (Makkar et al., 2007) and exhibit anti-tumor, anti-inflammatory, anti-ulcer, anti-atherosclerotic and anticonvulsant activities (Chumark et al., 2008). Seeds possess several interesting biological activities including antioxidant, antimicrobial, anticancer, anti-inflammatory, antiasthmatic activities as well as hepatoprotective and hypotensive effects (Hamza, 2010). Roots are used as stimulant and diuretic while the bark act as analgesic, antiinflammatory and antiviral (Siddhuraju and Becker, 2003). All these activities are due to $M$. oleifera bioactive compounds which has been reported to possess 46 antioxidant compounds including flavonoids, phenolic compounds, carotenoids, and ascorbic acid (Anwar et al., 2007; Adedapo et al., 2009; El-Alfy et al., 2011).

It is worthwhile stating, however, that intrinsic factors such as age and cultivar of the plant and extrinsic factors including extraction solvent, postharvest treatment, harvesting season, sunlight, soils, region of cultivation affect the phytochemical composition and antioxidant activity of plant materials (Tlili et al., 2014). Gelain et al. (2012) indicated that bioactive concentrations in plants are strongly dependent on the prevalence of growing conditions and its impact on the accumulation of related natural products. Plants belonging to the same species but occurring in different geographical zones may significantly differ in qualitative and quantitative content of their particular bioactive compounds (Szakiel et al., 2011). Therefore, different preparations from plants harvested from distinct locations in the world may produce different results (Tlili et al., 2014). Whether these concentrations increase or decrease in response to differences in growth environmental conditions, is still not clear.

M. oleifera phytochemical screening and antioxidant activity have been previously reported but scientific evidences on the comparison in their phytochemical composition as well as antioxidant activity at different geographical locations remains obscure. It was hypothesized that the phytochemical composition and antioxidant activity of $M$. oleifera does not vary with geographical zones. On this basis, the present study was designed to study the effect of different harvest sites with regard to the phytochemical composition and antioxidant activity of $M$. oleifera leaves, seeds and barks aqueous extracts from Bukavu city in DRC and Machakos County in Kenya.

\section{Material and Methods}

\section{Geographical Locations}

Fresh Moringa leaves, barks and dry seeds were collected from Bukavu city, East of DR Congo and Masii village of Machakos County in Kenya in July 2019. All laboratory works were done in the laboratory of phytochemistry, Centre for Traditional Medicine and Drug Research of the Kenya Medical Research Institute (KEMRI) in Kenya.

The city of Bukavu, capital of the Province of South Kivu, is located in the East of the DR Congo between $2^{\circ} 30^{\prime} 55^{\prime \prime}$ South latitude and 28 50'42" East longitude precisely in the basin called Eastern Valley Grabben (region of the great lakes). With an altitude of between $1.500 \mathrm{~m}$ and $2.194 \mathrm{~m}$ above sea level Bukavu has a climate similar to that of sub-equatorial or humid tropics (of short duration). Two seasons are available: the rainy season (lasting more or less 8 months from September to midMay) and the dry season (commences from July to midSeptember). The average temperature is around $20^{\circ} \mathrm{C}$ throughout the temperate coast and due to the presence of Lake Kivu the rainfall varies between $1.000 \mathrm{~mm}$ and 2.500 $\mathrm{mm}$ with an annual average of $1.320 \mathrm{~mm}$. The soil of Bukavu is much more compact, less impermeable and less porous since at the slightest drought, water runoff is experienced.

Machakos County, on the other hand, is found in Kenya and located between latitude $-1^{\circ} 31^{\prime} 0.01^{\prime \prime} \mathrm{S}$ and longitude $37^{\circ} 16^{\prime} 0.01^{\prime \prime} \mathrm{E}$ and has very unique physical and topographical landscapes. Machakos is found between 790 to $1594 \mathrm{~m}$ above sea level while small plateau reaching 1800-2100 m above sea level accompanied by Hills constitute the Central part of the County. Machakos soils are dark red clay, shallow and well drained particularly in the plains. The vegetation of the whole County of Machakos is depending on the particular altitude of each area/location. The average rainfall ranges between $500 \mathrm{~mm}$ and $1300 \mathrm{~mm}$. October and December are usually the expected months of the short rains whereas the long rains are predictable in March to May. Through the year, the temperature is ranged between $18^{\circ} \mathrm{C}$ and $29^{\circ} \mathrm{C}$ with July as the coldest month while October and March are the warmest months of the year. The maps showing the location of Bukavu city (DR Congo) and Machakos County (Kenya) are represented in Figure 1.

\section{Plant Collection and Preparation}

The plant materials of M. oleifera (Lam) aged 2 to 3 years were collected and taxonomically identified at the Department of Biology, University of Nairobi, Kenya. The leaves, seeds and barks were air dried at 24 to $31^{\circ} \mathrm{C}$ for 14 days. An electric mill was used to ground the plant materials after spreading and the fine powder was collected and stored in airtight glassware until use. 
BUKAVU CITY, EASTERN DR CONGO

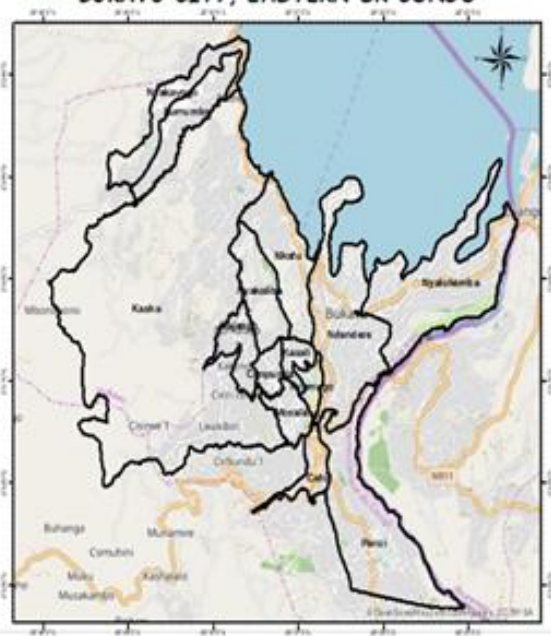

(a)

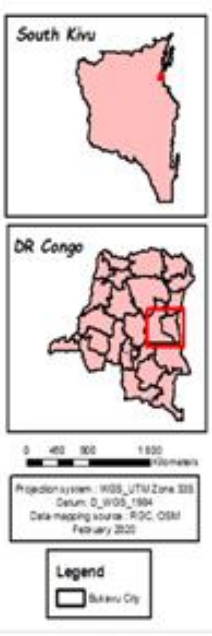$$
\text { . }
$$

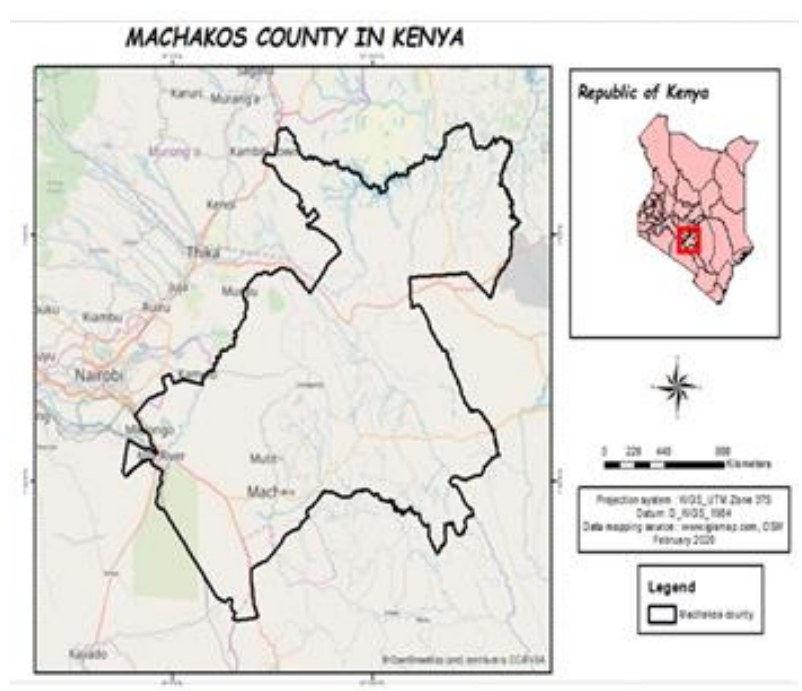

(b)

Figure 1. Map of Bukavu city in DR Congo (a) and Machakos county in Kenya (b)

\section{Extraction of Crude Powdered Sample}

The $M$. oleifera powder (300 g) was dried, then, using a bottle wrapped in aluminum foil, a total of $70 \mathrm{ml}$ of distilled water was added to it. With gentle stirring, the distilled water was gradually added to the powder until a slurry of uniform texture was formed. Thus, with a magnetic bar and a stirrer operating at 200 RPM for 48 hours, the phytochemicals present in the powder were extracted. The resulting slurry was centrifuged at 3000 RPM for 5 minutes and the supernatant was then collected in light-resistant bottles and freeze-dried.

Qualitative Analysis of the Phytochemicals of Moringa oleifera Aqueous Extracts Samples

To identify the presence of bioactive compounds such as phenols, saponins, alkaloids, flavonoids, tannins, terpenoids and glycosides, simple chemical tests were performed according to standard methods developed by Harborne (1988) and Evans and Trease (2009). Alkaloids were performed according to Dragendorff test while the presence of saponin was identified using foam test and ferric chloride test was used for detection of phenolic compounds. The presence of flavonoids was observed using alkaline reagent test and the Keller-Killiani test was used to identify glycosides while the test of Salkowski was used to assess the presence of terpenoids and the ferric chloride test for tannins. The resultant color development was reported as presence (+) or nil (-) following the color intensity developed from the reactions.

Quantitative Analysis of the Phytochemical's Constituents of Moringa oleifera Aqueous Extracts Samples

The determination of the quantity of alkaloids present in the samples was performed following the method of Harborne (1973) while the method proposed by Ejikeme et al. (2014) was used to determine the percentage of saponins and flavonoids. The percentage of total phenols in the samples was evaluated using Edeoga et al. (2005) method while Amadi et al. (2004) procedure was used to evaluate the glucoside content. The method described previously by Ferguson (1956) was used to determine the terpenoid content and tannin content was determined following the procedure described by Van-Burden and Robinson (1981).

\section{Antioxidant Activity}

The 2,2-diphenyl-1-picrylhydrazyl (DPPH) assay was used to assess the antioxidant activity in $M$. oleifera samples (Siddhuraju and Becker, 2003; Williams et al., 2004). The DPPH free radical scavenging activities of the crude extracts from the different parts of M. oleifera were evaluated as previously described by Zhu et al. (2011) and Bal et al. (2019). The quantity of the extract that react with $50 \%$ of DPPH radicals represented the $50 \%$ inhibitory concentration $\left(\mathrm{IC}_{50}\right)$.

\section{Statistical Analysis}

The obtained results were submitted to one-way ANOVA and significant difference between means were observed when $\mathrm{P}$ - value $<0.05$. results were expressed as mean \pm SD of three replicates. The XL STAT for Windows 10 software was used for statistical analyses.

\section{Results}

Preliminary Phytochemical Screening of Moringa oleifera Leaves, Seed and Bark Extracts

The phytochemical characteristics of leaves, seeds and barks of $M$. oleifera from Bukavu city and Machakos County are summarized in Table 1 . The results revealed the presence of glycosides in all the plant parts with absence of terpenoids in seeds from DRC and phenols and flavonoids in barks from Kenya and DR Congo. Alkaloids were absent in leaf samples while saponins absent in seeds collected from Kenya and DR Congo while tannins were absent in barks and seeds of samples collected from Kenya. 
Aqueous Extract Yield (Percentage Weight by Weight) from Leaves, Seeds and Barks of Moringa oleifera

Water was used as solvent for its efficiency in extracting antioxidant compounds from 100 grams of $M$. oleifera leaves, seeds and barks. The use of aqueous solvent produced more extract when using leaves of $M$. oleifera from DR Congo while seeds and barks had the same yield. Samples collected in Kenya had the highest yield in seeds followed by leaves and barks (Figure 2).

Quantitative Phytochemical Analysis of Leaves, Seeds and Barks of Moringa oleifera from DRC and Kenya

Results of Table 2 indicate that glycoside in seeds from DRC had the highest concentration $(6.17 \%)$ followed by alkaloids in seeds from Kenya $(5.56 \%)$ and saponin in barks from Kenya (5.33\%). Where available, terpenoids and flavonoids had low concentration in all samples compared to other compounds.

\section{Antioxidant Activity by DPPH Free Radical Scavenging Assay \\ Antioxidant activity result with free radical inhibition} method DPPH (2,2-diphenyl-1-picrylhydrazyl) from $M$. oleifera aqueous extract in leaves, seeds and barks collected from DRC and Kenya is indicated in table 3. The result of DPPH free radical scavenging activity showed that $M$. oleifera leaf and seed extracts have appreciable and concentration-dependent increase in scavenging effect with the fraction of the leaves being the most active compared to the seeds and barks. At the highest concentration $(10 \mu \mathrm{g} / \mathrm{mL})$, the mean percentage antioxidant inhibition for aqueous extract of leaves, seeds and barks from Kenya and DRC were 88.29 \pm 1.12 , $80.17 \pm 3.59, \quad 30.08 \pm 0.80,33.21 \pm 2.62,37.34 \pm 10.26$ and $41.86 \pm 2.01$, respectively whereas the reference standard (ascorbic acid) had a mean percentage inhibition of $92.63 \pm 2.76$ at $10 \mu \mathrm{g} / \mathrm{mL}$ (Table 3).

\section{IC 50 Value in Selected Aqueous Extracts}

The $\mathrm{IC}_{50}$ value refers the concentration that will scavenge $50 \%$ of the initial DPPH radicals. Evaluation of the IC50 as shown in Table 4 indicated that the leaves from Kenya and DRC exhibit the highest antioxidant activities (23.59 $\mu \mathrm{g} / \mathrm{mL}$ and $28.67 \mu \mathrm{g} / \mathrm{mL}$ respectively) compared to IC50 values of seeds and barks from the two geographical zones and much lower compared to that of the ascorbic acid $(3.16 \mu \mathrm{g} / \mathrm{mL})$, which was considered as the reference standard.

Table 1. Phytochemical composition of aqueous extracts of Moringa oleifera leaf, seed and bark collected from Bukavu city and Machakos County.

\begin{tabular}{l|ccccccc}
\hline \multirow{2}{*}{ Chemical groups } & \multicolumn{3}{c}{ Leaves } & \multicolumn{2}{c}{ Seeds } & \multicolumn{2}{c}{ Barks } \\
\cline { 2 - 8 } & Kenya & DRC & Kenya & DRC & Kenya & DRC \\
\hline Alkaloids & - & - & + & + & + & - & + \\
Saponins & + & + & + & + & + & + \\
Phenols & + & + & + & + & - & - \\
Flavonoids & + & + & + & + & + & + \\
Glycosides & + & + & + & - & + & + & + \\
Terpenoids & + & + & + & + & + & - \\
Tannins & + & & + & + & + & + \\
\hline
\end{tabular}

Table 2. Percentage of crude phytochemicals in aqueous extract of Moringa oleifera leaf, seed and bark collected from Bukavu city and Machakos County.

\begin{tabular}{l|cccccc}
\hline \multirow{2}{*}{ Chemical groups (\%) } & \multicolumn{2}{c}{ Leaves } & \multicolumn{2}{c}{ Seeds } & \multicolumn{2}{c}{ Barks } \\
\cline { 2 - 7 } & Kenya & DRC & Kenya & DRC & Kenya & DRC \\
\hline Alkaloids & - & - & 5.56 & 3.12 & - & 2.46 \\
Saponins & 1.78 & 3.78 & - & - & 5.33 & 4.92 \\
Phenols & 3.47 & 2.84 & 3.88 & 0.97 & 1.98 & - \\
Flavonoids & 0.84 & 0.71 & 0.53 & 0.51 & - & - \\
Glycosides & 4.34 & 3.89 & 4.18 & 6.17 & 4.86 & 4.61 \\
Terpenoids & 0.53 & - & 0.25 & 0.57 & - & 0.46 \\
Tannins & 3.73 & 4.12 & - & - & 1.65 & - \\
\hline
\end{tabular}

Table 3 DPPH-scavenging activity of aqueous extract of Moringa oleifera leaf, seed and bark collected from Bukavu city and Machakos County

\begin{tabular}{|c|c|c|c|c|c|c|c|}
\hline \multirow{3}{*}{$\begin{array}{l}\text { Concentration } \\
\qquad(\mu \mathrm{g} / \mathrm{mL})\end{array}$} & \multicolumn{7}{|c|}{ Percentage Inhibition } \\
\hline & \multirow{2}{*}{$\begin{array}{l}\text { Ascorbic } \\
\text { acid }\end{array}$} & \multicolumn{2}{|c|}{ Leaves } & \multicolumn{2}{|c|}{ Seeds } & \multicolumn{2}{|c|}{ Barks } \\
\hline & & Kenya & DRC & Kenya & DRC & Kenya & DRC \\
\hline 0.5 & $41.12 \pm 1.16$ & $28.02 \pm 3.47$ & $22.19 \pm 2.53$ & $15.44 \pm 6.51$ & $14.63 \pm 2.42$ & $17.01 \pm 1.13$ & $14.29 \pm 1.41$ \\
\hline 1 & $64.35 \pm 2.28$ & $42.11 \pm 4.23$ & $25.81 \pm 1.88$ & $15.74 \pm 0.42$ & $14.21 \pm 3.67$ & $21.38 \pm 4.37$ & $25.09 \pm 3.53$ \\
\hline 2 & $77.49 \pm 5.21$ & $44.17 \pm 0.65$ & $37.85 \pm 3.32$ & $17.40 \pm 1.71$ & $22.34 \pm 3.29$ & $24.58 \pm 4.62$ & $27.38 \pm 0.70$ \\
\hline 5 & $84.36 \pm 1.28$ & $62.83 \pm 0.14$ & $51.22 \pm 13.03$ & $21.93 \pm 2.34$ & $27.14 \pm 4.95$ & $30.17 \pm 2.66$ & $34.82 \pm 0.70$ \\
\hline 10 & $92.63 \pm 2.76$ & $88.29 \pm 1.12$ & $80.17 \pm 3.59$ & $30.08 \pm 0.80$ & $33.21 \pm 2.62$ & $37.34 \pm 10.26$ & $41.86 \pm 2.01$ \\
\hline
\end{tabular}


Table 4. $\mathrm{IC}_{50}$ of aqueous extract of Moringa oleifera leaf, seed and bark collected from Bukavu city and Machakos county.

\begin{tabular}{l|cc}
\hline \multirow{2}{*}{ Sample } & Origin & $\mathrm{IC}_{50}$ \\
\cline { 2 - 3 } & Ascorbic acid (reference standard) & $3.16 \mu \mathrm{g} / \mathrm{mL}$ \\
\hline \multirow{2}{*}{ Leaves } & Kenya & $23.59 \mu \mathrm{g} / \mathrm{mL}$ \\
& DRC & $28.67 \mu \mathrm{g} / \mathrm{mL}$ \\
\hline \multirow{2}{*}{ Seeds } & Kenya & $64.21 \mu \mathrm{g} / \mathrm{mL}$ \\
& DRC & $72.94 \mu \mathrm{g} / \mathrm{mL}$ \\
\hline \multirow{2}{*}{ Barks } & Kenya & $84.11 \mu \mathrm{g} / \mathrm{mL}$ \\
& DRC & $75.48 \mu \mathrm{g} / \mathrm{mL}$ \\
\hline
\end{tabular}

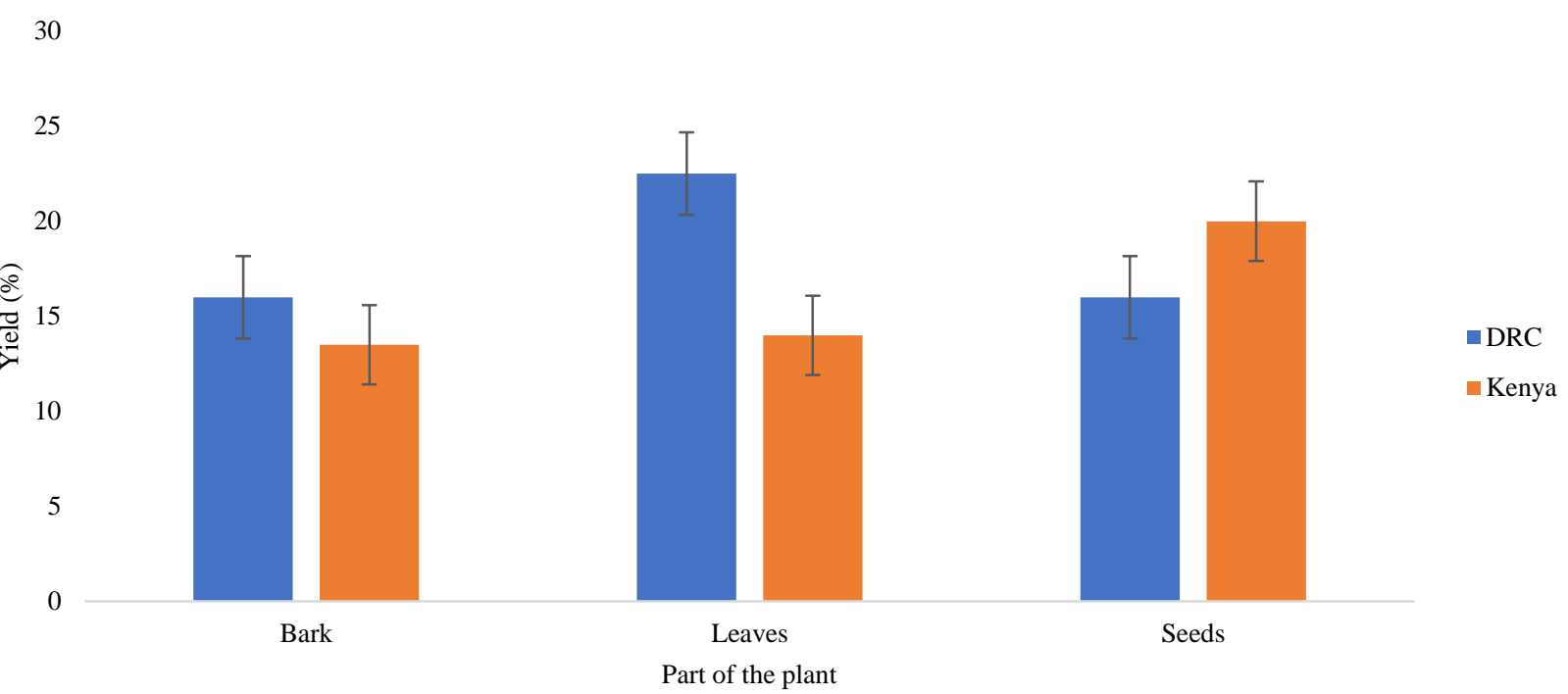

Figure 2. Yield of aqueous extracts of Moringa oleifera leaf, seed and bark collected from Bukavu city and Machakos county.

\section{Discussion}

Results on phytochemical screening of the aqueous extract of leaves, seeds and barks of $M$. oleifera collected from DRC and Kenya indicated that compounds such as alkaloids, saponins, phenols, flavonoids, glycosides, terpenoids and tannins are found in leaves, seeds or barks of the same plant. These results agree with findings of Barreira et al. (2008) on leaves, seeds and stembark of $M$. oleifera and Ayirezang et al. (2020) on leaves and seeds of $M$. oleifera. It was previously reported that, in these parts of $M$. oleifera, the presence of these phytochemicals is a great indicator of the medicinal potential of the plant (Ifesan et al., 2013). In fact, several findings have reported that secondary metabolites present in many plant extracts possess a lot of pharmacological proprieties such as hypoglycemic ((Tlili et al., 2014) and anti-hypertensive effects (Da Costa et al., 2018).

Due to their good antioxidant activities, these compounds are associated to several biological effects such as antitumor and anti-inflammatory activities (Sharma et al., 2011). In fact, alkaloids have diverse pathophysiological effects including antimitotic, analgesic, antibacterial, hypnotic, anti-inflammatory, local anesthetic, hypnotic, antitumor and psychotropic activity (Chisholm, 2015). Saponins are used as foaming agents in carbonated beverages and cosmetics, as emulsifiers in preparations containing lipophilic colors or flavors, as preservatives, and for removal of dietary cholesterol (Güçlü-Ustündağ and Mazza, 2007). Phenolic compounds can be used as antibiotics and antidiarrheal, antiulcer, and anti-inflammatory agents, as well as for the treatment of diseases such as hypertension, vascular fragility, allergies, hypercholesterolemia (Saito et al., 1998; Pehlivan et al., 2021). Flavonoids are well known to protect enzyme systems, cardiovascular diseases, cancers, steroid hormone-dependent cancers, and other age-related diseases (Yao et al., 2006). Glycosides have been shown to suppress or inhibit growth of one type of cells (microbial, fungal, tumor, genetically altered, etc.) and do not or to a lesser extent affect the growth of host cells (Chisholm et al., 2015). Many terpenes have biological activities and are used for medical purposes; they have antioxidant, anticonvulsant, antiulcer, anti-inflammatory, antiseptic, antitumor, antiviral, analgesic, antihypertensive, antibacterial, and therapeutic antidiabetic properties (Vuerich et al., 2019). Tannins have shown many health promoting properties like antiviral, anti-inflammatory, immune modulator and antioxidant effects (Manzoor et al., 2020).

Results of the present study showed that leaves from Kenya and DRC seem to have many bioactive compounds compared to seeds and barks but with no alkaloids. These results agree with the findings of Unuigbe et al. (2014) which reported absence of alkaloids in leaves but present in seeds of $M$. oleifera. According to Nantongo et al. (2018), the concentration of alkaloids can only be discovered in $20 \%$ of the plant species particularly in 
young, actively growing tissues. Therefore, the production and abundance of alkaloids are mainly related to factors that affect growth of fresh plant tissues such as light, soil nutrients and moisture, temperature and other physicochemical factors (Kirk et al., 2010; DesgagnéPenix, 2017).

It is well known that flavonoids endow a wide range of pharmacological and biochemical properties, such as antimicrobial and anti-inflammatory activities as well as inhibition of platelet aggregation (Kang et al., 2010). In the present study the flavonoids were not detected in bark but abundant in leaves compared to seeds from Kenya and DRC. Although not the focus of our study, the results of the present study are in agreement with the findings of Tlili et al. (2014) in Searsia tripartita (Ucria) Moffett which reported variation in flavonoid content from different localities and stage of maturity and with a decrease observed in advanced maturity of the plant (Menichini et al., 2008).

Total phenol and glycoside concentration were higher in leaves, seeds and barks of $M$. oleifera from Kenya compare to those from DRC. The observed variation in these metabolites have been reported among and within plant species primarily due several factors such as genetic factors (Adesina, 2006; Sun et al., 2013), environmental effects and their interaction (War et al., 2012). In fact, when growth conditions are not the same, especially nitrogen availability, the abundancy of phenolic compounds in plant tissues can vary from plant to plant within the same species. For insistance, nitrogen deficiency or limitation leads to phenolic accumulation in different plant parts (Larbat et al., 2014).

The concentration of terpenoids seems to be very low in each plant part when compared to other compounds in plant samples collected from DRC and Kenya. Generally, in most plants the common order of secondary metabolites with respect to abundance is phenolics > alkaloids > cyanogenic glycosides $>$ tannins $>$ flavonoids and saponins $>$ terpenoids (Nantongo et al., 2018). In addition, concentrations of terpenoids in plant tissues are regulated by the availability of substrate and the activity and type of biosynthetic enzymes. Therefore, emission rates of volatile terpenoids from plant leaves are controlled by their synthesis rates and compound-specific physicochemical characteristics, mainly their solubility, volatility and diffusivity (Ferguson, 1956). These are affected by physicochemical constraints caused by temperature, stomatal conductance and leaf structure. Rapid changes in the physiological status e.g., stomatal function and allocation of resources (i.e., substrate availability) at high temperatures could have dramatic changes in production of terpenes by plants. This can explain the low terpenoids concentration recorded in this study as Moringa samples were collected during dry season when sunlight was stinging (Nantongo et al., 2018).

Leaves of $M$. oleifera collected from DRC showed a higher extraction yield $(22.5 \%)$ compared to other plant parts. This result is comparable to findings of Ayirezang et al. (2020) in M. oleifera aqueous leaf extracts (24.9\%) when compared to seeds $(11.45 \%)$ but much higher compared to those reported by Okumu et al. (2016) where M. oleifera aqueous extraction yield was approximately $14.23 \%$. The observed variance is attributed to a large variability of bioactive compounds and their high concentration found in this study and reported by several authors (Okumu et al., 2016; Kumbhare et al., 2012).

The 2,2-diphenyl-1-picrylhydrazyl assay is one of the most widely used methods and has become routine in establishing the antioxidant activity of herbal extracts and phytochemicals. DPPH is known to obstruct labile hydrogen and the ability to scavenge the DPPH radical is related to the inhibition of lipid per oxidation (Zheng and Wang, 2001). The result of DPPH radical scavenging activity showed that aqueous extract of $M$. oleifera leaves from DRC and Kenya have the highest inhibition percentage depending on the concentration used. These results are comparable to those of Unuigbe et al. (2014) in leaves and seeds of $M$. oleifera. At the highest concentration $(10 \mu \mathrm{g} / \mathrm{mL})$, the percentage inhibition was $88.29 \pm 1.12,80.17 \pm 3.59$ for leaves from Kenya and DRC respectively, $30.08 \pm 0.80,33.21 \pm 2.62$ for seeds from Kenya and DRC respectively and $37.34 \pm 10.26,41.86 \pm 2.01$ for barks from Kenya and DRC respectively, whereas the reference standard (ascorbic acid) had a percentage inhibition of $92.63 \pm 2.76$. This result is in accordance with findings of Unuigbe et al. (2014), Tlili et al. (2014) and Sharma et al. (2011) who reported that, in most cases, sample concentrations do not exceed the ascorbic acid concentration (considered as the standard). The evaluation of the $\mathrm{IC}_{50}$ in this study indicate that aqueous extract of $M$. oleifera leaves from DRC and Kenya exhibit the highest antioxidant activity with $\mathrm{IC}_{50}$ value of $23.59 \mu \mathrm{g} / \mathrm{mL}$ and $28.67 \mu \mathrm{g} / \mathrm{mL}$ respectively. This is the result of the large variability and concentration of bioactive compounds in leaves compared to seeds and barks as reported in this study. These values were very low and different from that of the reference standard $(3.16 \mu \mathrm{g} / \mathrm{mL})$. These results concur with those of Unuigbe et al. (2014) where $\mathrm{IC}_{50}$ of $M$. oleifera leaf and seed samples were lower than that of ascorbic acid (standard). However, the $\mathrm{IC}_{50}$ values of $M$. leaves were very high compared to Kenyan seeds (64.21 $\mu \mathrm{g} / \mathrm{mL})$ and barks $(84.11 \mu \mathrm{g} / \mathrm{mL})$ and DRC seeds $(72.94$ $\mu \mathrm{g} / \mathrm{mL})$ and barks $(75.48 \mu \mathrm{g} / \mathrm{mL})$.

\section{Conclusion}

In this study, a phytochemical characterization and antioxidant activity comparisons of $M$. oleifera leaves, seeds and barks collected from DR Congo and Kenya were carried out. Results clearly indicated that the composition and concentration in bioactive compounds as well as antioxidant capacity of $M$. oleifera vary significantly across geographical regions and the different plant parts used. In this work, we also reported the richness of leaf extracts from DRC and Kenya compared to seeds and barks. Based on this observation, leaves, especially those from Kenya, are recommended as a satisfactory antioxidant. However, despite their low composition in bioactive compounds and antioxidant capacity compared to leaves, seeds and barks also have pharmacological proprieties. Our study has for the first time provided insights into the use of $M$. oleifera seeds and barks as important natural source of antioxidant and this can offer reprieve on the over use of leaves hence conservation of ecosystem. 


\section{Acknowledgments}

The present study was fully supported by the Université Evangélique en Afrique through the project on research and teaching capacity building graciously funded by Pain pour le Monde (grant number: A-COD-2018-0383).

Special thanks to Mr. Patrick Mutiso, department of Biology, University of Nairobi, Kenya for Moringa oleifera taxonomical identification.

\section{References}

Adedapo AA, Mogbojuri OM, Emikpe BO. 2009. Safety evaluations of the aqueous extract of the leaves of Moringa oleifera in rats. J Med Plants Res, 3: 586-591

Adesina S. 2006. The Nigerian Zanthoxylum; chemical and biological values. Afr J Trad Compl and Alt, 2 (3): 282-301

Amadi BA, Agomuo EN, Ibegbulem CO. 2004. Research Methods in Biochemistry, Supreme Publishers, Owerri, Nigeria.

Anwar F, Latif S, Ashraf M, Gilani AH. 2007. Moringa oleifera Lam.: a food plant with multiple medicinal uses. Phyto Res, 21: $17-25$

Ayirezang FA, Azumah BK, Achio S. 2020. Effects of Moringa oleifera Leaves and Seeds Extracts against Food Spoilage Fungi. Adv Microbio, 10: 27-38 https://doi.org/10.4236/aim.2020.101003

Bal C, Sevindik M, Akgul H, Selamoglu Z. 2019. Oxidative stress index and antioxidant capacity of Lepista nuda collected from Gaziantep/Turkey. Sigma, 37(1): 1-5.

Barreira JCM, Ferreira ICFR, Oliveira MBPP, Pereira JA. 2008. Antioxidant activity and bioactive compounds of ten Portuguese regional and commercial almond cultivars. Food Chem Toxicol, 46(6): 2230-2235 doi:10.1016/ j.fct.2008.02.024

Chisholm H. 2015. Encyclopedia Brittanica, A Dictionary of Arts, Sciences, Literature and General Information. 22. New York: Sagwan Press, ISBN-13: 9781340141998 https://www.britannica.com

Chumark P, Khunawat P, Sanvarinda Y, Phornchirasilp S, Morales NP, Phivthong-Ngam L, Klai-upsorn SP. 2008. The in vitro and ex vivo antioxidant properties, hypolipidaemic and antiatherosclerotic activities of water extract of Moringa oleifera Lam. leaves. J of Ethno, 116: 439-446

Da Costa CDF, Herculano EA, Silva JCG, Paulino ET, Bernardino AC, Araújo-Júnior JX, Sant'ana AEG, Salvador MJ, Ribeiro ÊAN. 2018. Hypotensive, vasorelaxant and antihypertensive activities of the hexane extract of Anacardium occidentale Linn. Arch Biol Sci, 70(3): 459-68

Desgagné-Penix I. 2017. Distribution of alkaloids in woody plants. Plant Sci Today, 4 (3): 137-42

Edeoga HO, Okwu DE, Mbaebie BO. 2005. Phytochemical constituents of some Nigerian medicinal plants. Afr J Biotech, 4(7): 685-688 doi:10.5897/ajb2005.000-3127

Ejikeme CM, Ezeonu CS, Eboatu AN. 2014. Determination of physical and phytochemical constituents of some tropical timbers indigenous to Niger Delta Area of Nigeria. Eur Sci J, 10(18): 247-270

Ekor M, Adepoju GKA, Epoyun AA. 2006. Protective effect of the methanolic leaf extract of Persea americana (Avocado) against paracetamol-induced acute hepatotoxicity in rats. Int J Pharm, 2(4): 416-420

El-Alfy TS, Ezzat SM, Hegazy AK, Amer AM, Kamel GM. 2011. Isolation of biologically active constituents from Moringa peregrina (Forssk.) Fiori. (Family: Moringaceae) growing in Egypt. Pharmacog Mag, 7(26): 109-115

Evans WC, Trease GE. 2009. Pharmacognosy.16th ed. Edinburgh, UK, 353-415
Ferguson NM. 1956. A Text book of Pharmacognosy. Mac Milan Company, New Delhi 191.

Gelain DP, Behr GA, Birnfeld de Oliveira R, Trujillo M. 2012. Antioxidant Therapies for Neurodegenerative Diseases: Mechanisms, Current Trends, and Perspectives. Oxid Med and Cell Longev, ID 895153, 2. https://doi.org/ $10.1155 / 2012 / 895153$

Güçlü-Ustündağ O, Mazza G. 2007. Saponins: properties, applications and processing. Crit Rev Food Sci Nutr, 47(3): 231-58 doi: 10.1080/10408390600698197

Hamza AA. 2010. Ameliorative effects of Moringa oleifera Lam seed extract on liver fibrosis in rats. Food and Chem Toxicol, 48: $345-355$

Harbone JB. 1973. Phytochemical methods. London. Chapman and Hall, Ltd, 49-188.

Harborne JB. 1988. Introduction to Ecological Biochemistry.3rd edition. Academic Press, London.; 10-15

Ibrahim MA, Koorbanally NA, Islam, M.S. 2013. In vitro antioxidative activities of the various parts of Parkia biglobosa and GC-MS analysis of extracts with high activity. Afr. J. Trad., Compl. and Alternativ, 10(5): 283-291. DOI: 10.4314/ajtcam.v10i5.10

Ifesan BOT, Fashakin JF, Ebosele F, Oyerinde AS. 2013. Antioxidant and antimicrobial properties of selected plant leaves. Eur J Med Plant, 3(3): 465-473

Ikpeme EV, Ekaluo UB, Udensi OU, Ekerette EE. 2014. Screening fresh and dried fruits of avocado pear (Persea americana) for antioxidant activities : An alternative for synthetic antioxidant. J. Life Sci Res Disc, 1: 19-25

Kang J, Li Z, Wu T, Jensen GS, Schauss AG, Wu X. 2010. Antioxidant capacities of flavonoid compounds isolated from acai pulp (Euterpe oleracea Mart.). Food chem, 122 (3): 610-617 https://doi.org/10.1016/j.foodchem.2010.03.020

Kirk H, Vrieling K, Van Der Meijden E, Klinkhamer PGL. 2010. Species by environment interactions affect pyrrolizidine alkaloid expression in Senecio jacobaea, Senecio aquaticus, and their hybrids. J Chem Ecol, 36 (4): 378-87

Kumbhare MR, Guleha V, Sivakumar T. 2012. Estimation of total phenolic content, cytotoxicity and in-vitro antioxidant activity of stem bark of Moringa oleifera. Asian Pac J Trop Dis, 144-150

Larbat R, Paris C, Le Bot J, Adamowicz S. 2014. Phenolic characterization and variability in leaves, stems and roots of Micro-Tom and patio tomatoes, in response to nitrogen limitation. Plant Sci, 224: 62-73. http://dx.doi.org/ 10.1016/j.plantsci.2014.04.010

Luqman S, Srivastava S, Kumar R, Maurya AK, Chanda D. 2012. Experimental assessment of Moringa oleifera leaf and fruit for Its antistress, antioxidant, and scavenging potential using in vitro and in vivo assays. Ev Based Compl and Alt Med, 519084

Mahmood KT, Mugal T, Haq IU. 2010. Moringa oleifera: A natural gift-A review. J of Pharm, 2: 775-781

Makkar HPS, Francis G, Becker K. 2007. Bioactivity of phytochemicals in some lesser-known plants and their effects and potential applications in livestock and aquaculture production systems. Animal, 1(9): 1371-1391 doi: 10.1017/S1751731107000298

Manzoor F, Nisa MU, Hussain HA, Ahmad N, Umbreen H. 2020. Effect of different levels of hydrolysable tannin intake on the reproductive hormones and serum biochemical indices in healthy female rats. Scientific Reports, 10,20600. https://doi.org/10.1038/s41598-020-77672-0

Menichini F, Tundis R, Bonesi M, Loizzo R, Conforti F, Statti G, De Cindio B, Houghton PJ, Menichini F. 2008. The influence of fruit ripening on the phytochemical content and biological activity of Capsicum chinense Jacq. cv Habanero. Food Chem, 114(2): 553-560 
Mohammed FS, Günal S, Şabik AE, Akgül H, Sevindik M. 2020. Antioxidant and Antimicrobial activity of Scorzonera papposa collected from Iraq and Turkey. Kahramanmaraş Sütçü İmam Üniversitesi Tarım ve Doğa Dergisi, 23(5): 1114-1118.

Molla MR, Rahman MM, Akter F, Mostofa M. 2012. Effects of Nishyinda, black pepper and cinnamon extract as growth promoter in broilers. The Bangl Vet, 29(2): 69-77

Mutwedu VB, Ayagirwe RBB, Bacigale SB, Mwema LM, Butseme S, Kashosi T, Mitima B, Manyawu GJ, Nyongesa AW. 2019. Effect of dietary inclusion of small quantities of Mucuna pruriens seed meal on sexual behavior, semen characteristics and biochemical parameters in rabbit bucks (Oryctolagus cuniculus). Trop An Health Prod, 51(5): 11951202 doi.org/10.1007/s11250-019-01808-2

Mutwedu VB, Nyongesa AW, Azine PC, Chiregereza DK, Ngoumtsop VH, Mugumaarhahama Y, Ayagirwe RBB. 2021. Growth performance and reproductive function impairment of glyphosate- based herbicide in male guinea pig (Cavia porcellus). J An Physiol and An Nutr, 7(3):1047-1055 DOI: $10.1002 /$ vms 3.443

Nantongo JS, Odoi JB, Abigaba G, Gwali S. 2018. Variability of phenolic and alkaloid content in different plant parts of Carissa edulis Vahl and Zanthoxylum chalybeum Engl. BMC Res Notes, 11: 125

Ngoumtsop VH, Ngoula F, Kenfack A, Mutwedu BV, Nguemmogne TG, Tchoffo H, Azafack KD, Deutcheu NS, Manjeli Y. 2017. Effects of Oxidative Stress Induced by Antouka Super (Insecticide) ${ }^{\circledR}$ on Some Reproductive Parameters of Male Japanese Quail (Coturnix coturnix japonica) and Mitigation Strategies Using Aqueous Leaves Extract of Persea americana. Glob Vet, 18(4): 242-249 DOI: 10.5829/idosi.gv.2017.242.249

Nimse SB, Pal D. 2015. Free radicals, natural antioxidants, and their reaction mechanisms." RSC Advances, 5: 27986-28006.

Ojewole JA, Amabeoku CJ. 2006. Anticonvulsant effect of Persea Americana Mill (Lauraceae) (Avocado) leaf aqueous extract in mice. Phyto Res, 20 (8): 696-700.

Okumu MO, Mbaria JM, Kanja LW, Gakuya DW, Kiama SG, Ochola FO. 2016. Phytochemical profile and antioxidant capacity of leaves of Moringa oleifera (Lam) extracted using different solvent systems. J Pharm and Phytochem, 5(4): 302308

Pehlivan M, Mohammed FS, Şabik AE, Kına E, Dogan M, Yumrutaş Ö, Sevindik M. 2021. Some Biological activities of ethanol extract of Marrubium globosum. Turkish Journal of Agriculture-Food Science and Technology, 9(6): 1129-1132.

Pehlivan M, Mohammed FS, Sevindik M, Akgul H. 2018. Antioxidant and oxidant potential of Rosa canina. Eurasian Journal of Forest Science, 6(4): 22-25.

Saito M, Hosoyama H, Ariga T, Kataoka S, Yamaji N. 1998. Antiulcer activity of grape seed extract and procyanidins. J Agr Food Chem, 46 (4): 1460-4

Sevindik M, Akgul H, Korkmaz AI, Sen I. 2018. Antioxidant potantials of Helvella leucomelaena and Sarcosphaera coronaria. J Bacteriol Mycol Open Access, 6(2): 00173.

Sevindik M. 2019. Wild edible mushroom Cantharellus cibarius as a natural antioxidant food. Turkish Journal of AgricultureFood Science and Technology, 7(9): 1377-1381.

Sharma V, Paliwal R, Pracheta Sharma S. 2011. Phytochemical analysis and evaluation of antioxidant activities of hydroethanolic extract of Moringa oleifera Lam. Pods J Pharm Res, 4(2): 554-557
Siddhuraju P, Becker K. 2003. Antioxidant properties of various solvent extracts of total phenolic constituents from three different agroclimatic origins of drumstick tree (Moringa oleifera Lam.) leaves. J Agric Food Chem, 51(8): 2144-2155

Siddhuraju P, Becker K. 2003. Antioxidant Properties of Various Solvent Extracts of Total Phenolic Constituents from Three Different Agroclimatic Origins of Drumstick Tree (Moringa oleifera Lam.) Leaves. J Agr and Food Chem, 51: 2144-2155

Sun B, Zhang F, Zhou G, Chu G, Huang F, Wang Q, Jin L, Lin F, Yang J. 2013. Genetic variation in alkaloid accumulation in leaves of Nicotiana. J Zhejiang Univ-Science B, 14(12): 1100

Szakiel A, Paczkowski C, Henry M. 2011. Influence of environmental abiotic factors on the content of saponins in plants. Phyto Rev, 10: 471-491

Tlili N, Mejri H, Yahia Y, Saadaoui E, Rejeb S, Khaldi A, Nasri N. 2014. Phytochemicals and antioxidant activities of Rhus tripartitum (Ucria) fruits depending on locality and different stages of maturity. Food chem, 160: 98-103 https://doi.org/10.1016/j.foodchem.2014.03.030

Tremellen K. 2008. Oxidative stress and male infertility-a clinical perspective. Hum Reprod Update, 14(3): 243-258. doi:10.1093/humupd/dmn004.

Unuigbe CA, Okeri HA, Erharuyi O, Oghenero EE, Obamed DA. 2014. Phytochemical and antioxidant evaluation of Moringa oleifera (Moringaceae) leaf and seed. J Pharm and Biores, 11(2): 51-57 http://dx.doi.org/10.4314/jpb.v11i2.4

Van Buren JP, Robinson WB. 1981. Formation of Complexes between Protein and Tannic Acid. J Agr Food Chem, 17: 772 $-777$

Vijayakumar S, Dhanapal R, Sarathchandran I, Kumar SA, Ratna V. 2012. Evaluation of antioxidant activity of Ammania baccifera (L.) whole plant extract in rats. Asian Paci J Trop Biomed, 753-756

Vuerich M, Ferfuia C, Zuliani F, Piani B, Sepulcri A, Baldini M. 2019. Yield and quality of essential oils in Hemp varieties in different environments. Agronomy, 9: 356-373

Wadhwa S. 2013. A Review on commercial, traditional uses, phytoconstituents and pharmacological activity of Moringa oleifera. Global J of Trad Med Syst, 2(1): 01-13

War AR, Paulraj MG, Ahmad T, Buhroo AA, Hussain B, Ignacimuthu S, Sharma HC. 2012. Mechanisms of plant defense against insect herbivores. Plant Sign and Behav, 7(10):1306-20

Williams RJ, Spencer JP, Rice-Evans C. 2004. Flavonoids: antioxidants or signalling molecules? Free Rad Biol Med, 36:838-849

Xu YB, Chen GL, Guo MQ. 2019. Antioxidant and AntiInflammatory Activities of the Crude Extracts of Moringa oleifera from Kenya and Their Correlations with Flavonoids. Antioxidants, 8(8): 296 doi:10.3390/antiox8080296

Yao LH, Jiang YM, Shi J, Tomas-Barberan FA, Datta N, Singanusong R, Chen SS. 2004. Flavonoids in Food and Their Health Benefits. Plant Foods Hum Nutr, 59: 113-122. https://doi.org/10.1007/s11130-004-0049-7

Zheng W, Wang SY. (2001). Antioxidant activity and phenolic compounds in selected herbs. J Agr Food Chem, 49: 51655170 .

Zhu KX, Lian CX, Guo XN, Peng W, Zhou HM. 2011. Antioxidant activities and total phenolic contents of various extracts from defatted wheat germ. Food Chem, 126(3): 1122-1126 doi:10.1016/j.foodchem.2010.11.14 